CORRECTION

\title{
PHARMACOTHERAPY OF ADDICTIONS
}

Mary Jeanne Kreek, K. Steven LaForge and Eduardo Butelman

Nature Reviews Drug Discovery 1, 710-726 (2002)

On page 720 of the article, the sentence that cited reference 121, which read:

"It is of interest that a recent report of cocaine self-administration in CRF receptor 1 (Crfrr ) knockout mice (potentially equivalen to the administration of a life-long CRF-receptor antagonist) showed increased cocaine self administration when the mice were placed under intermittent stress ${ }^{121}$,"

should have read:

"It is of interest that a recent report of alcohol self-administration in CRF receptor $1(\mathrm{Crfr} 1)$ knockout mice (potentially equivalent to the administration of a life-long CRF-receptor antagonist) showed increased alcohol self administration when the mice were placed under intermittent stress ${ }^{121}$ "

as reference 121 dealt with alcohol, not cocaine.

This correction has been made to the online version of the Review. 